\section{Birlesik Dünya Arastırma International Journal of BD-CENTER \\ Learning and Teaching}

Innovasyon ve Yayıneılık Merkezi

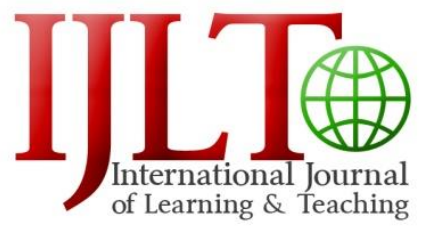

\title{
Parental and lecturers' involvement towards students' homework: A case study of engineering and non-engineering students at State Polytechnic of Sriwijaya
}

Welly Ardiansyah*, State Polytechnic of Sriwijaya, Jl. Srijaya Negara, Palembang 30139, Indonesia https://orcid.org/0000-0002-8411-7307

Nurul Aryanti, State Polytechnic of Sriwijaya, Jl. Srijaya Negara, Palembang 30139, Indonesia https://orcid.org/0000-0002-7105-8651

Murwani Ujihanti, State Polytechnic of Sriwijaya, Jl. Srijaya Negara, Palembang 30139, Indonesia https://orcid.org/0000-0002-8280-9780

Achmad Leofaragusta K. K., State Polytechnic of Sriwijaya, Jl. Srijaya Negara, Palembang 30139, Indonesia https://orcid.org/0000-0001-7622-8691

\section{Suggested Citation:}

Ardiansyah, W., Aryanti, N., Ujihanti, M. \& Leofaragusta, A. K. K. (2020). Parental and lecturers' involvement towards students' homework: A case study of engineering and non-engineering students at State Polytechnic of Sriwijaya. International Journal of Learning and Teaching. 12(4), 189-201. https://doi.org/10.18844/iilt.v12i4.5021

Received June 24, 2020; revised August 15, 2020; accepted October 20, 2020.

Selection and peer-review under the responsibility of Prof. Dr. Hafize Keser, Ankara University, Ankara, Turkey. ${ }^{\circ} 2020$ Birlesik Dunya Yenilik Arastirma ve Yayincilik Merkezi. All rights reserved.

\begin{abstract}
The purpose of the study was to focus on parents and lecturers' involvement in the homework of students. The participants consisted of parents of engineering and non-engineering students in State Polytechnics of Sriwijaya and its teaching staff. The sample consisted of 150 parents of $95 \%$ high-income status and 24 certified lecturers. The research used a quantitative approach. Data were collected via surveys answered by parents and lecturers based on Likert scale items adapted from Reglin, Cameron, and Losike-Sedimo. The results showed that parental involvement towards students' homework completion and partnerships between parents and lecturers were very low. Since educational gains of parental involvement are noted and confirm the significance of parents in educational processes, it is recommended that parents who do not assist their children in homework should be sensitised to do so.
\end{abstract}

Keywords: Parent involvement, homework, partnership.

* ADDRESS FOR CORRESPONDENCE: Welly Ardiansyah, English Department of State Polytechnic of Sriwijaya, Jl. Srijaya Negara Bukit Besar, Palembang 30139, Indonesia. E-mail address: ardiansyahwelly@gmail.com / Tel.: +62-81274822878 
Ardiansyah, W., Aryanti, N., Ujihanti, M. \& Leofaragusta, A. K. K. (2020). Parental and lecturers' involvement towards students' homework: A case study of engineering and non-engineering students at State Polytechnic of Sriwijaya. International Journal of Learning and Teaching. 12(4), 189-201. https://doi.org/10.18844/ijlt.v12i4.5021

\section{Introduction}

Students whose parents are actively involved in their education have higher academic achievement than students whose parents are not actively involved in their education. Homework can cause greater parental involvement in class and it can also end in increased differences between high and low achievers. The involvement of oldsters in their child's education is believed to be one of the foremost important aspects of educational achievement and is believed to enhance the connection between home and school.

Parental involvement in homework is often a tool to keep parents well informed of the child's strengths and weaknesses in several subject areas particularly reading. By the same token, other educational researches have repeatedly established the advantages of effective homework concurrence, actively involved parents help to extend and stimulate a child's interest in the class and encourage academic achievement for students and families (Carr, 2013). Sad and Gurbuzturk (2013) agreed that homework for children can have a long-term developmental effect. Homework can help and develop not only good study habits and positive attitudes towards school, but also conveys to students that learning happens outside also as inside the school. This study explores the possibilities that parental involvement with homework does occur and makes a difference in the academic success of students, since it is anticipated that students will routinely pursue parental involvement while completing homework assignments.

This study tried to gather information on the effects of parental involvement in students' homework based on a survey of parents. The research was designed to answer the subsequent questions: Does parental involvement in homework impact students' achievement? How can teachers involve parents in the homework process?

\section{Literature review}

\subsection{Homework}

Homework creates different challenges for parents, students and teachers. Parents feel helpless at times because of not understanding the content or the assignment, students refuse to complete homework or forget assignments at school, and teachers become frustrated with the lack of support from parents and students who do not complete their homework assignments (Vorhees, 2011). Van Voorhis (2011) points out that many parents lack the will, time and knowledge to help their child with homework. Also, $\mathrm{Xu}$ and $\mathrm{Wu}$ (2013) argue that many parents are not helping their children in their learning process at home and school work. They are not aware that they are important teachers in their children's lives.

Students often form their own attitudes about homework (Ramdass \& Zimmerman, 2011). Students who claim there is no point in homework feel that they get nothing out of it and teachers place no value theorem. Students assume that teachers do not care about homework because they do not collect, read, grade or use the homework in class. Since teachers do not collect, check or grade the homework, students feel they might as well not complete it (Galloway, Conner \& Pope, 2013). Students who claim they do not have enough time for homework explain the need for social life (Xu \& $\mathrm{Wu}, 2013)$. Students acknowledge that they sometimes skip homework because they want to spend time with their friends. Students confess that they sometimes forgo homework and opt otherwise to simply get out of the house, have guests over, attend parties, listen to music or talk with friends. Another reason some students admit finding time for homework difficult is thanks to their involvement in after-school activities.

To overcome such problems, Fox (2016) suggests teachers assign homework regularly and consistently to get students into the habit of doing homework and establishing a pattern which students may follow. Also, he believes that teachers should communicate with parents by sending the 
policy home for parents to read, sign and return. He goes on to offer other ideas such as making homework count as a grade, making assignments varied and interesting, accommodating varied ability levels, providing personal and targeted feedback and making available support and advice for parents on how to help their child's learning at home. Gutierrez and Rogoff (2003) advise parents to keep aside a uniform learning time for homework. This means deciding if the student will work on homework right after school or wait until after dinner. He also adds that 'learning time' should be a family activity in which the parent models enthusiasm for learning by reading a book or by doing his/her work-related tasks.

\subsection{Parent involvement at home}

Parent involvement is one of the most important things to improve children's behaviour and achievement in schooling processes. It will be achieved by involving parents in the schooling process at home, such as in motivating, facilitating and assisting the student. Singh et al. (1995), as cited by Fan and Chen (2001), stated that many facts show that some aspects of parent involvement possibly have more obvious consequences for children's academic progress than others. Furthermore, parent involvement is important in learning because it will enhance students' motivation and achievement.

The participation of parents at home is assisting their children in learning. This engagement consists of the control and support of learning. For example, control of learning is asking if the children have homework or assignments from school, suggesting to their children to finish their homework. On the other hand, support for learning is by giving facilities such as a smartphone, the internet, and a laptop. Then, parents also provide additional learning, recite the Qur'an and ask about difficulties in doing homework from friends or neighbours who have more understanding.

Finally, parent involvement at home is not only the parents' responsibility for health and safety, but also in doing homework. It has a close relationship with their behaviour. Wilder (2014) said that homebased involvement in the way parents educate their children at home enhances their children's academic achievement.

\subsection{Parental involvement and homework}

The worst part of homework for youngsters and adolescents could also be that it is a solitary activity; the effect improves considerably as a shared activity with parents or peers. Parents who assist with homework play a critical role not only in fostering learning but also in scaffolding strategies for time management and problem-solving. Besides, their interest in and assistance with homework predicts their children's self-perceptions of competence. Parent involvement is important to enhance the tutorial achievement of scholars. When the oldsters get involved in the learning process, the children will be motivated to do better at school. Wood (2003), as cited by Ibrahim and Jamil (2012), showed that parents who are involved in the varsity process of their children will enhance academic success at college. Participation of oldsters in learning, such as assisting their children in doing homework or assignments from school, being a volunteer, contributing through support and affirmation of their children's achievement can be identified by better grades, attendance, attitudes and homework completion (Smith, Wobhlstetter \& Pedro, 2011).

Parents also create environments for studies that help students learn to affect and manage their homework behaviour. In their observational study of oldsters and their third-grade children, Bempechat and Shernoff (2012) found that oldsters effectively arranged their children's homework environment by minimising distractions, focusing their children on their assignments, and helping to make homework more interesting. Children of those parents are actively engaged in strategies to assist them to complete their work, including preparing an area to figure, keeping track of your time and self-monitoring their effect by praising themselves. These children, then, are ready to model adaptive attitudes and behaviours that their parents have created for them. 
This and other studies demonstrate the extent to which homework is often a social experience, during which children's subjective experience is made through interactions with parents. Indeed, parents' attitudes about homework are found to possess an immediate and positive influence on their children's subsequent attitudes and academic outcomes (Jeynes, 2010).

The above-mentioned research makes clear that homework is often a strong vehicle for fostering the event of adaptive motivational tendencies. When parent involvement with homework is warm and supportive, it serves to reinforce both academic achievement and therefore the development of adaptive beliefs about learning.

\section{Methodology}

\subsection{Research design}

This research explores the possibilities that parental involvement with homework does occur and makes a difference in academic success. Therefore, this study is designed to examine the extent of parent involvement in their children's homework. The study took a quantitative approach based on two separate surveys of children's parents and lecturers.

\subsection{Participants}

The participants were parents of State Polytechnic of Sriwijaya students ranging from second to fourth semester; engineering and non-engineering approximately 150 parents consisting of $95 \%$ highincome status. Besides, the random sample from this diverse population of parents was surveyed. Certified lecturers were surveyed as well using a separate survey. These survey instruments were used to collect data, which were analysed according to responses.

\subsection{Instrumentation}

There are two survey instruments for this study. Both are from previously conducted research and include 12 items on the Likert scale adapted from Reglin, Cameron and Losike-Sedimo (2012). Responses are based on participants' answers by choosing SA = Strongly Agree, A = Agree, UD = Undecided, $D=$ Disagree and SD = Strongly Disagree, with all items on homework and parental involvement. Lastly, an open-ended question was included at the end of each survey for comments about issues or concerns not addressed in the questionnaire.

\subsection{Parent survey}

The parent survey relates to what extent of importance the parent believes parental involvement and parental involvement in homework is, and any comments or concerns could be expressed about parental involvement and homework.

\subsection{Teacher survey}

The survey instrument was used to collect data from certified lecturers. The part of the lecturer survey was based on the extent of parental involvement and homework and its importance according to the Likert scale. The range of the scale was from 1 to 5 , with 5 being the most agreed upon. The next survey allowed lecturers to include any comments or concerns about parental involvement and parental involvement in homework. 
Ardiansyah, W., Aryanti, N., Ujihanti, M. \& Leofaragusta, A. K. K. (2020). Parental and lecturers' involvement towards students' homework: A case study of engineering and non-engineering students at State Polytechnic of Sriwijaya. International Journal of Learning and Teaching. 12(4), 189-201. https://doi.org/10.18844/ijlt.v12i4.5021

\subsection{Data collection}

Surveys were distributed to parents and lecturers of students in the second and fourth semester of engineering and non-engineering student programmes.

\subsection{Data analysis}

A quantitative analysis was used to analyse the results of the surveys. The Likert scale had five response alternatives: strongly agree, agree, neither agree nor disagree, disagree and strongly disagree. The information was stored and kept in a database for statistical analysis.

\section{Findings and discussion}

\subsection{Parental involvement}

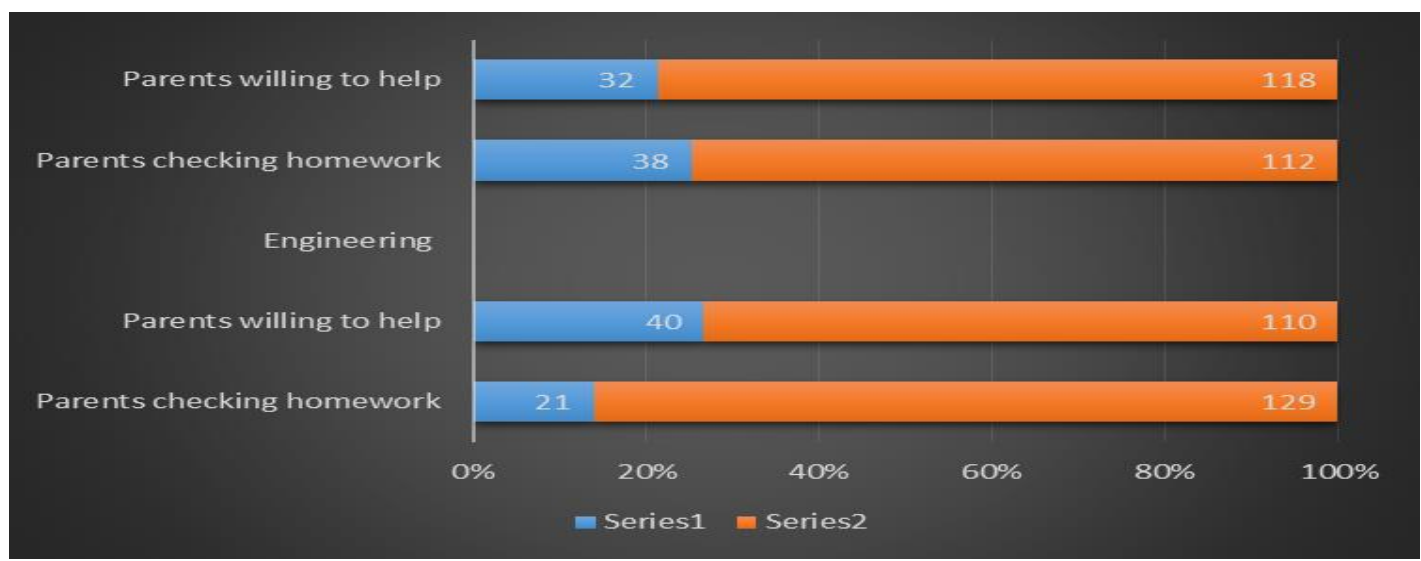

Figure 1. Parents who support homework efforts

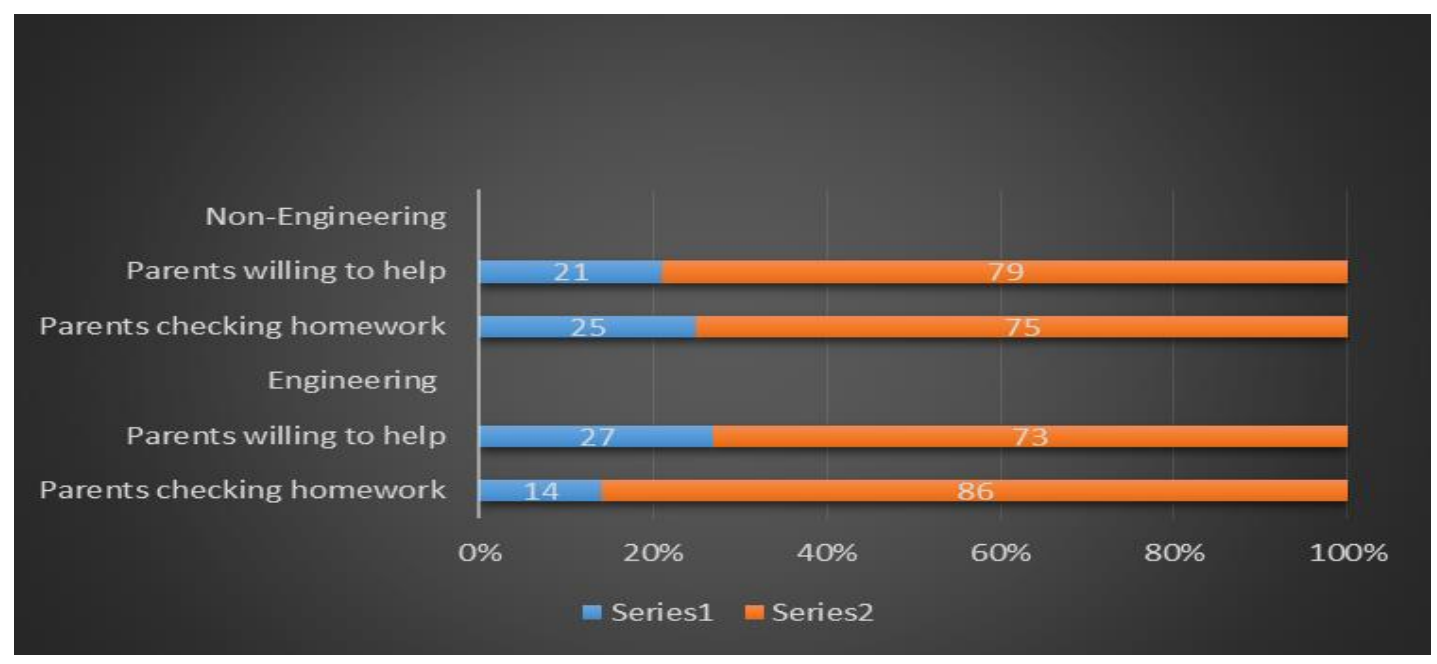

Figure 2. Parents who support homework efforts 
5. Figures 1 and 2 show that the majority of students did not have parents who supported their homework efforts. The data directly show that a lot of parents did not agree to offer support to the students by always checking homework and making sure it is done correctly.

6. Figure 3 provides information on the percentage of students' parents and their involvement in homework. The responses of parent involvement in this figure include (a) difficulty to be actively involved, and (b) several hours spent helping children understand the homework. The responses were divided into categories based on the involvement of parents with homework and included the following: (a) 1-5 (disagree), (b) 3 (undecided) and (c) 4-5 (agree).

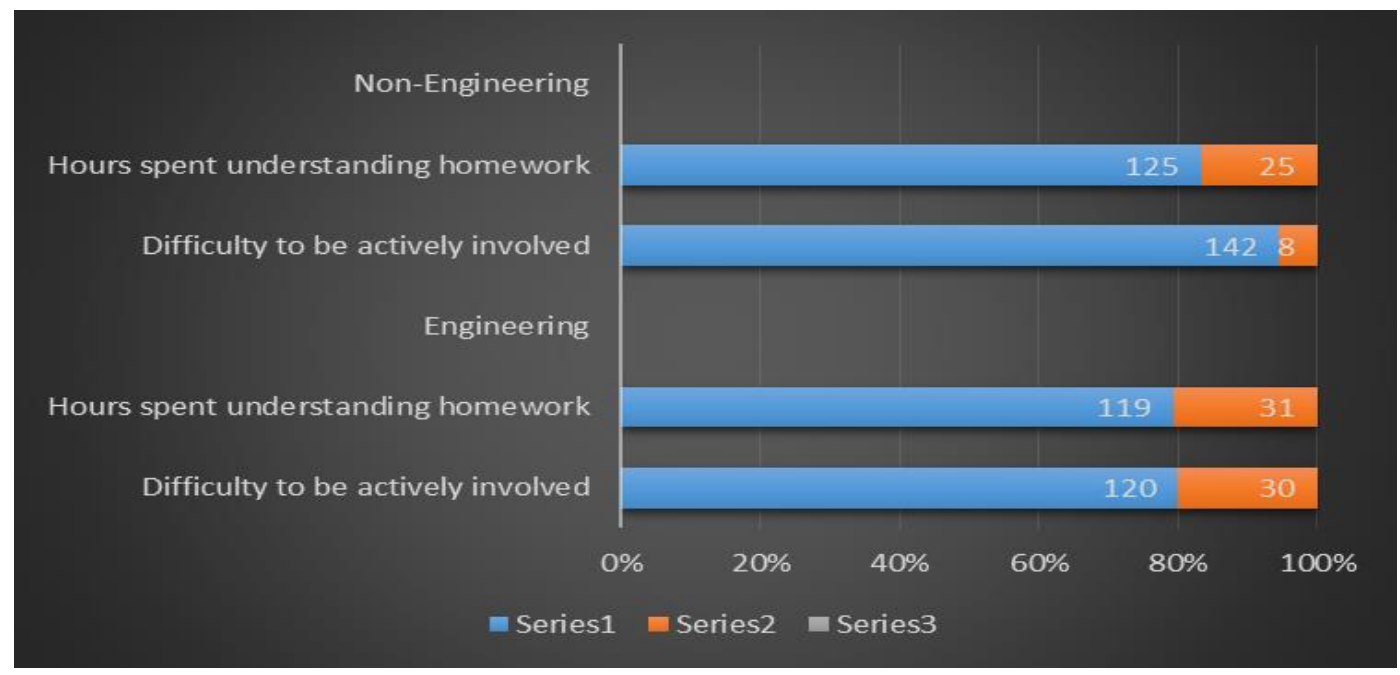

Figure 3. Parents who have a difficult time in involving and understanding homework

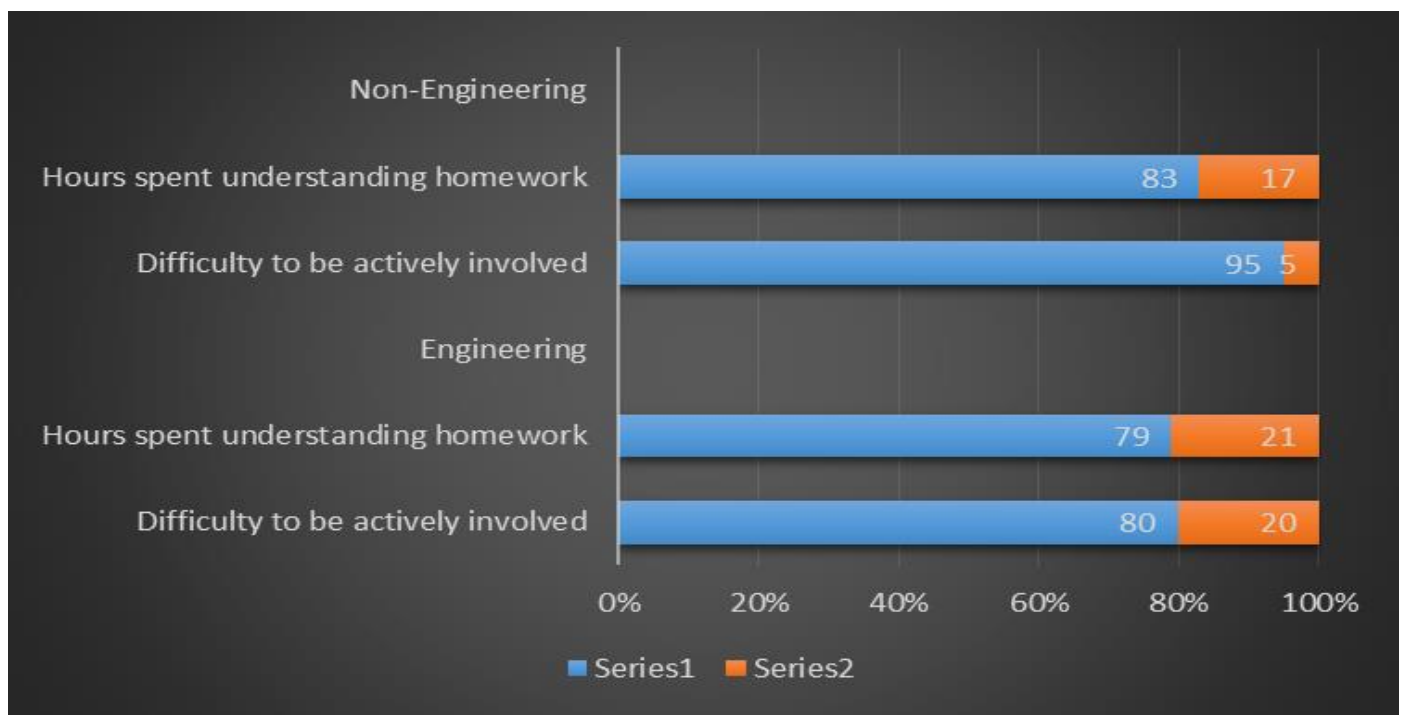

Figure 4. Parents who have a difficult time in involving and understanding homework

The data in Figure 4 show that the majority of students had parents who found it difficult to be actively involved in their homework and spent several hours understanding the homework. The data show that a large number of parents agreed there was a problem being actively involved in their child's education and are spending hours trying to understand the homework. 


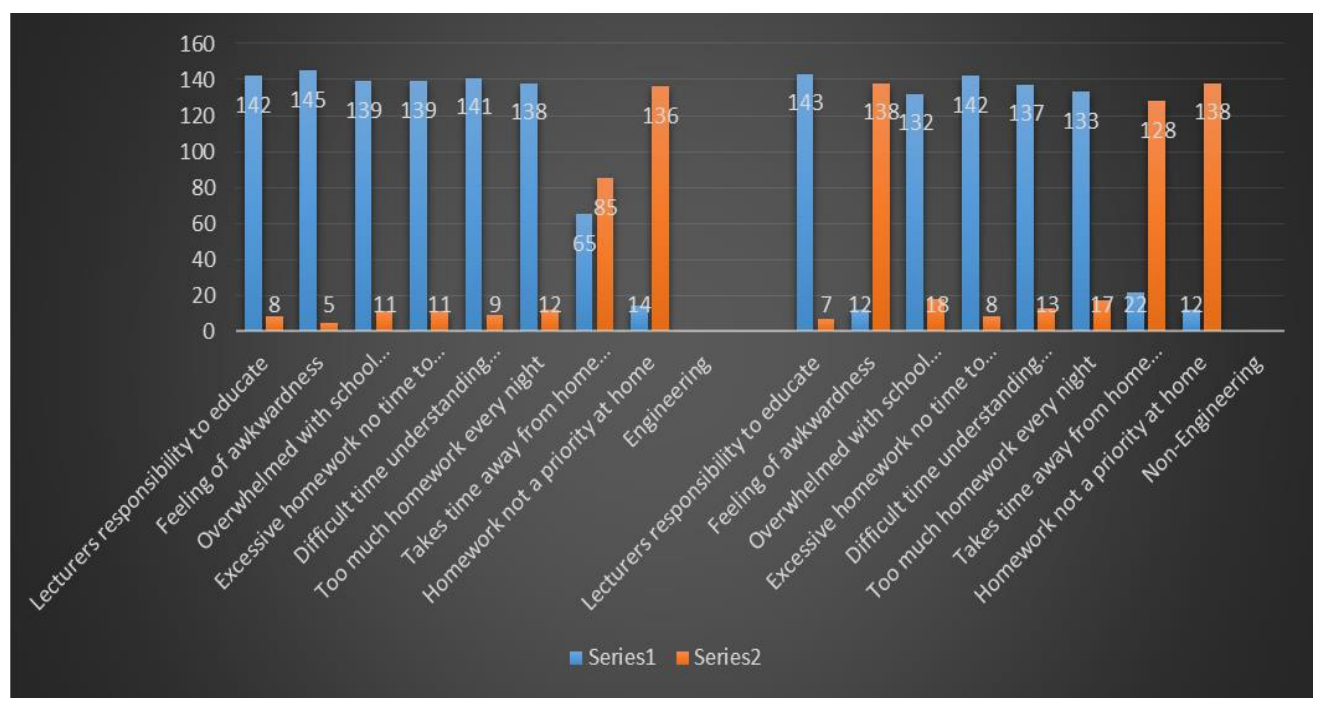

Figure 5. Parents who formed their own opinion about school and homework

7.

8. Figure 5 provides information on the percentage of students' parents and their attitudes towards their children receiving homework. The responses of parent attitude based on homework in this figure include (a) teacher's responsibility to educate students, (b) feeling awkward when at the child's school, (c) being overwhelmed by the educational process and programmes, (d) disproportionate homework with no time to help, (e) difficulty understanding homework to make corrections, (f) too much homework every night, (g) homework interrupting with home activities and $(\mathrm{h})$ homework should not be a priority. The responses were divided into categories based on the attitudes/opinions of parents on school issues and homework included the following: (a) 1-2 (disagree), (b) 3 (undecided) and (c) 4-5 (agree).

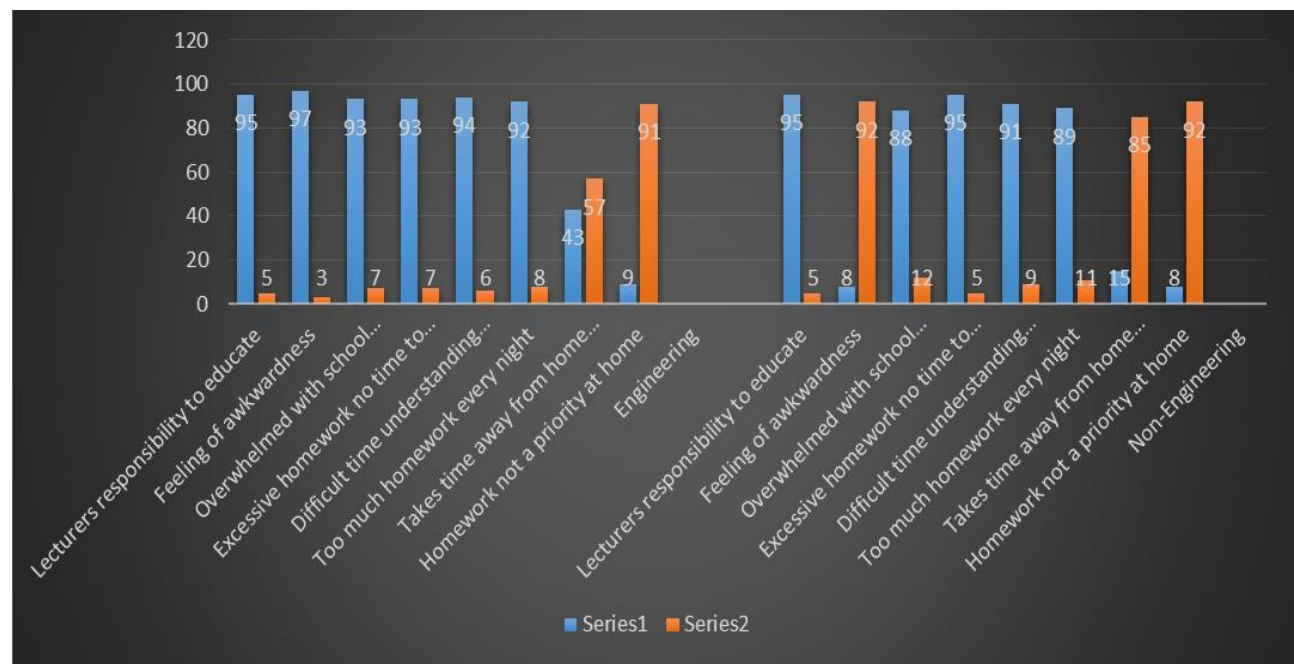

Figure 6. Parents who formed their own opinion about school and homework

Figure 6 shows that the majority of students' parent's attitudes out of the eight categories negatively rated their attitudes towards (a) lecturer's responsibility to educate students, (b) feeling awkward when at the child's school, (c) being overwhelmed by the educational process and 
programmes, (d) disproportionate homework with no time to help, (e) difficulty understanding homework to make corrections, (f) too much homework every night, (g) homework interrupting with home activities and (h) homework should not be a priority. The data show that there were not many issues about their child's education and homework.

\subsection{Teacher's perception}

Figure 7 provides information on the percentage of lecturers who collaborate with their colleagues and what they think of parents as partners. The responses of teacher collaboration in this figure were divided into categories and include (a) sharing strategies for student success and (b) lecturers and parents as partners. The responses were divided into categories based on the collaboration of lecturers and parent partnerships and included the following: (a) 1-2 (disagree), (b) 3 (undecided) and (c) 4-5 (agree).

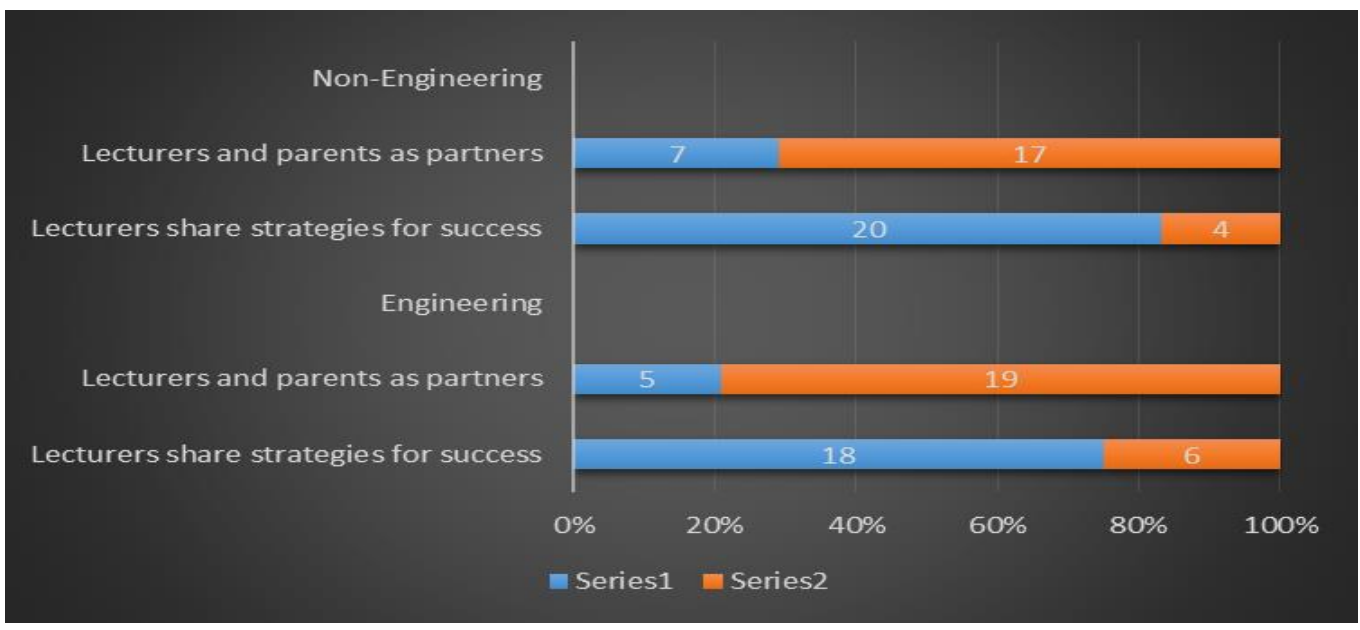

Figure 7. Lecturers and parents as partners

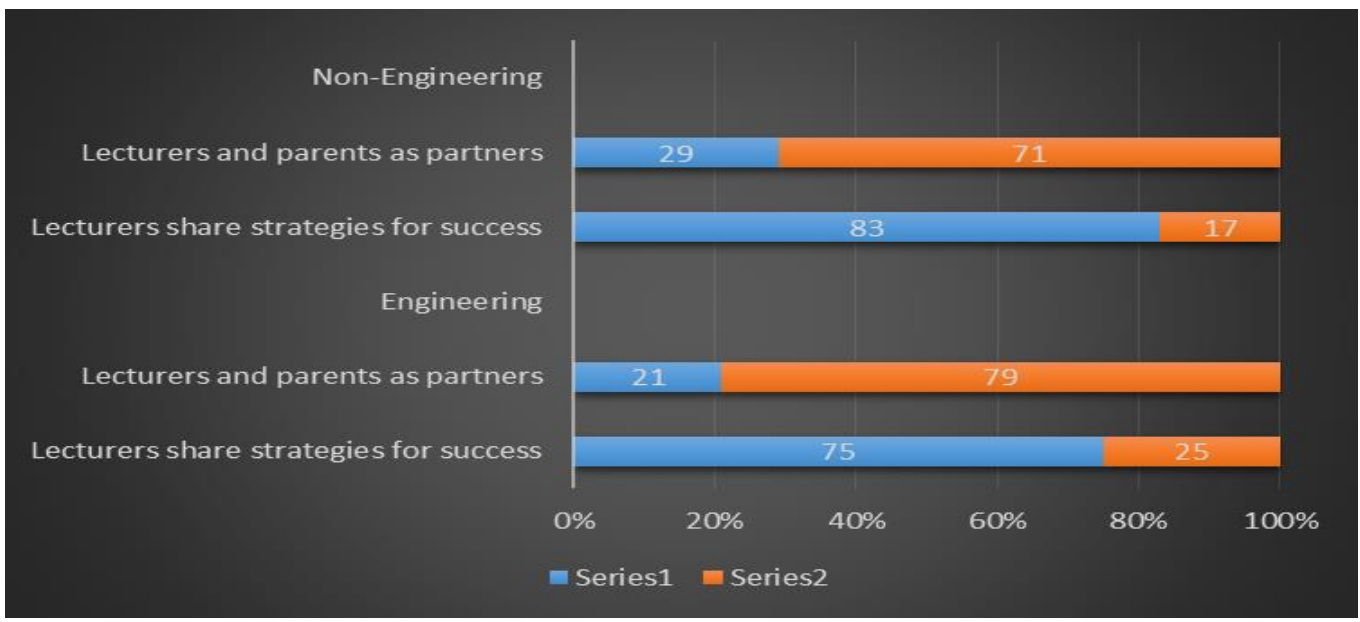

Figure 8. Lecturers share strategies for success and consider parents as partners

The data in Figures 7 and 8 show that the majority of lecturers do share strategies for the success of students and the majority of lecturers in category two did not consider parents as partners. The data in category one show that a large number of lecturers agreed there was collaboration going on for the success of the student. The data in category two showed that the majority of lecturers did not consider parents as partners. 
Figure 9 provides information on the percentage of lecturers rating the importance of parental involvement. The responses from lecturers on parent involvement in this figure include (a) rating parental involvement as excellent, (b) the importance of having parental involvement, (c) encouraging parental involvement, and (d) parents understanding the importance of parental involvement. The responses were divided into categories based on parental involvement and included the following: (a) 1-2 (disagree), (b) 3 (undecided) and (c) 4-5 (agree).

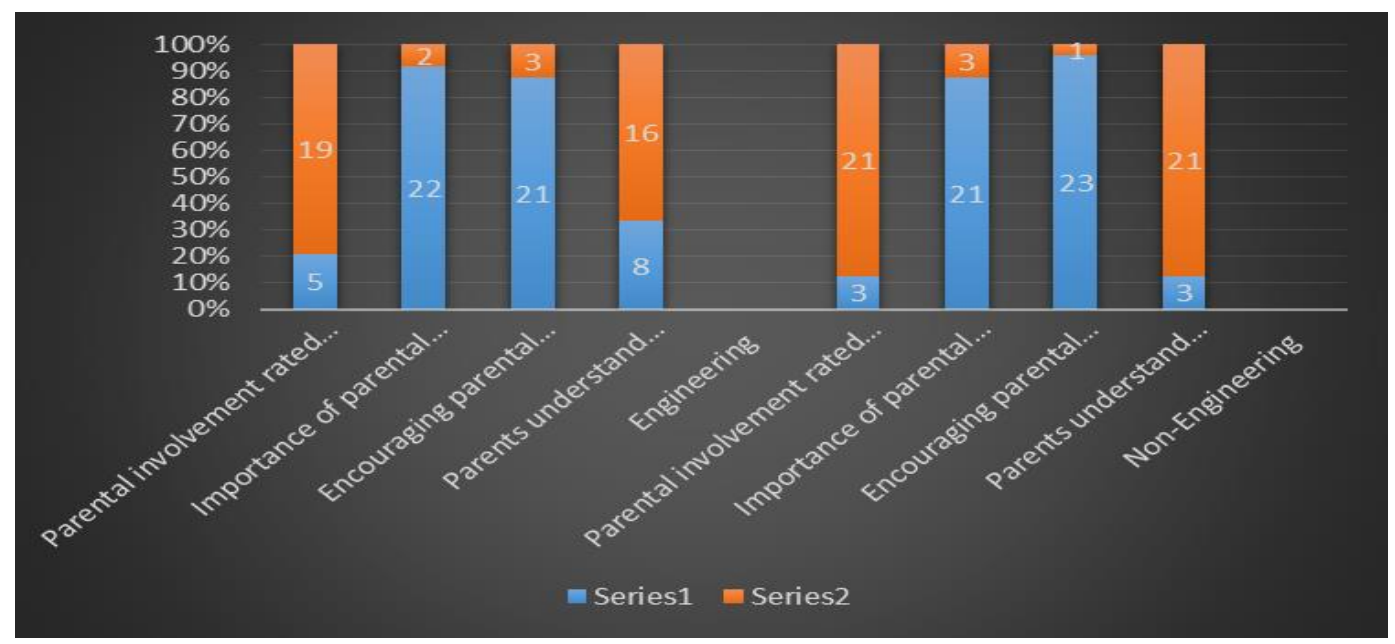

Figure 9. Parental involvement at home and school

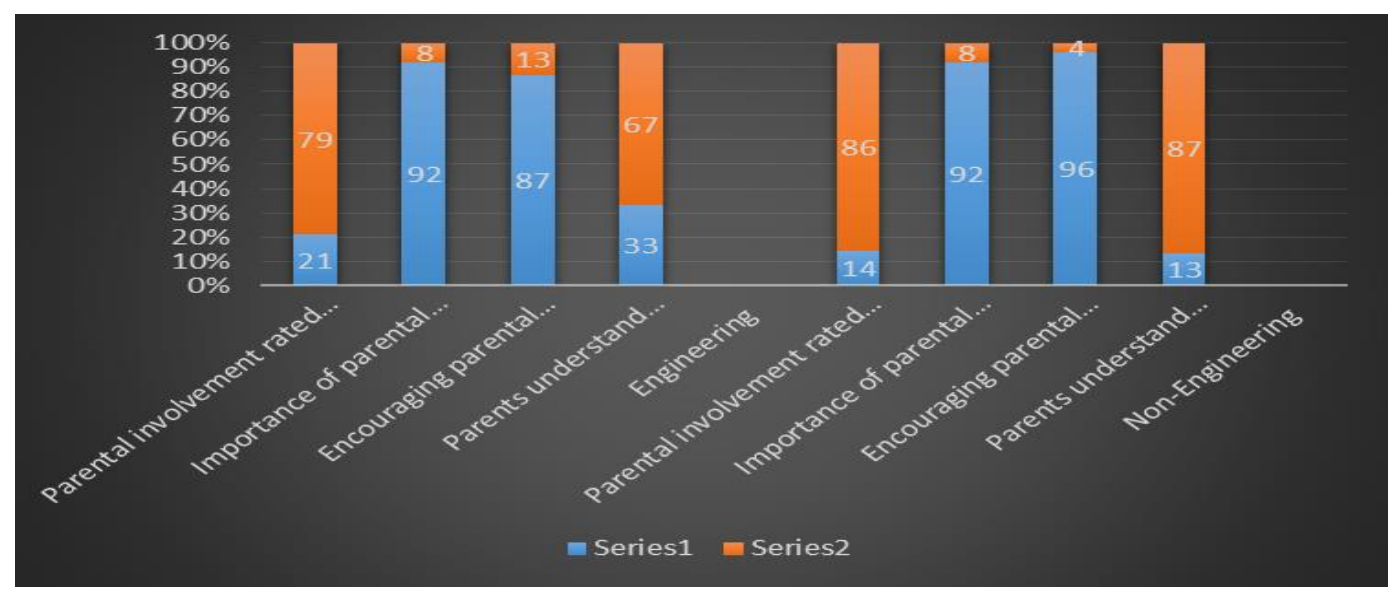

Figure 10. Engineering parental involvement at home and school

The data in Figures 9 and 10 show that the majority of lecturers negatively rated parent involvement as being excellent and parents knowing the importance of parental involvement. The data also showed that the majority of lecturers positively rated the importance of parental involvement as a lecturer and lecturer encouragement of parental involvement.

Figure 11 provides information on the percentage of lecturers' attitudes towards parental involvement in homework. The responses from lecturers on parent involvement in homework in this figure include (a) parents make sure homework is correct, (b) parents understand how homework is done, (c) parents can communicate with students about homework, (d) lecturers are considerate when giving out homework, (e) parents get involved and help with homework and (f) lecturers concerned if parents can help. The responses were divided into categories based on parental involvement and included the following: (a) 1-2 (disagree), (b) 3 (undecided) and (c) 4-5 (agree). 


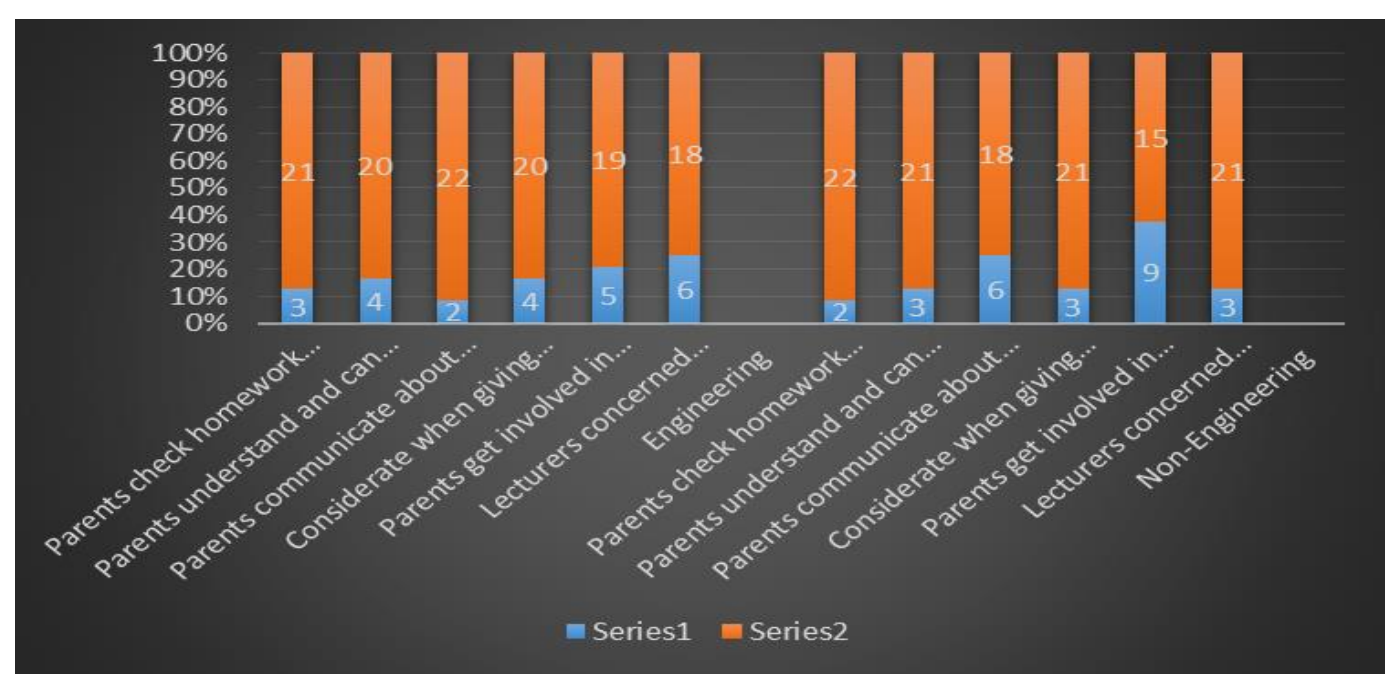

Figure 11. Lecturers' attitudes towards parents and homework

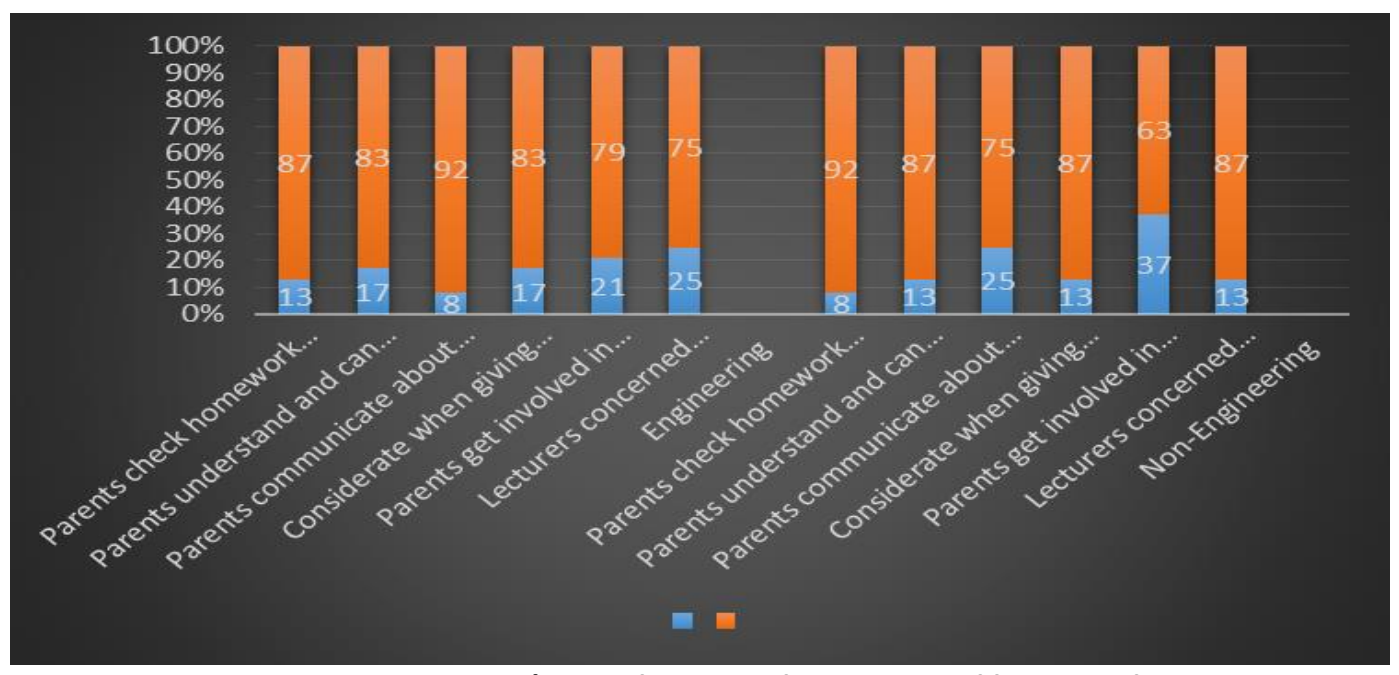

Figure 12. Lecturers' attitudes towards parents and homework

The data in Figures 11 and 12 show lecturers disagreed parents speak the language to communicate with their students about homework. They also disagreed there was a concern and that they are sure parents are not able to help their children with their homework assignments. Seemingly, all lecturers who participated in the survey disagreed they were considerate of the parents and the students when giving out homework assignments. The remaining three themes show that the lecturers did not agree parents check homework to make sure it was done correctly, that parents understood how to help their students with homework or get involved to make sure homework was done correctly. Also, the reasons why parental involvement is low were also found. They are no prior involvement, my kid is ok, parent abdicates responsibility, the 'new math', parents have no time (other jobs/odd hours) and parents have no time (elect other activities).

No prior involvement means that parents operating from this perspective were previously rarely involved in their child's education. They feel that since they have never really had much contact with the school or their child's teacher(s) they do not need to be involved now or at any time in the future. Parents may perceive their role as not involved or having anything to do with the formal education of their child. Interventions to involve these parents more would specialise in improving the home- 
school relationship. Such interventions would specialise in establishing a dialogue between the varsity as an entity and therefore the parent to explore each player's expectations of the opposite.

My kid is ok means that parents believe that their child is doing fine in school and further involvement on their part is not needed. This case may be typified by the child who has all A's except for a low or failing grade in one course. The parent minimises the importance of the one low grade under the idea that the kid has always been an honest student which is often undoubtedly an aberrant occurrence. Once again, as in the previous reason, there is a miscommunication between home and school as to what each expects of the other.

Parent abdicates responsibility means that parents feel it is the school's job to educate their child and refuse to take on any of that responsibility. The parents are uninvolved and out of touch with their child's educational process. This reason turns over psychology and emphasises the necessity for folks to once more own responsibility for their children's education. This reasoning is better known as the logic of confidence argument. School's interventions to succeed in abdicating parents might include inviting parents into the classroom as observers.

The New Math means that parents feel that the work the child is doing is beyond their expertise. Parents feel that they must be an expert in each subject. When they discover that they are not, they lose confidence in their ability to help. The research plainly shows, however, that parents' understanding of the work is not as important to student achievement as their willingness to undertake and help. Schools attempting to succeed with these types of parents could institute refresher parent education courses. These courses could emphasise the importance of the parent helping the child solve problems and helping to find the answers. The major intervention a faculty could make would be to assist the parent(s) to realise that they have not been ready to do the child's coursework. Schools can make parents facilitators to education no matter whether parents are ready or willing to be deliverers of education.

Parents have no time (other jobs/odd hours) mean that parents have no time to dedicate to being involved with their child's education and often work many hours per week or is not available when the child is available. This rationale often underlies the inability of some parents to attend scheduled meetings with lecturers or other school-related functions. There is no time. To succeed with this kind of parent, schools should check out the days they are offering for interaction with parents. Scheduling times other than the traditional 'after school' slot for parent meetings could help parents who have little time.

Parents have no time (elect other activities) means that they do not have time to devote to being involved with the school and/or their child's education. Unlike the parent who is functioning to take care of the family basic needs, these parents elect to interact in other activities like clubs or just a relaxing reception instead of working with their children. Schools should understand that there are parents whose attitudes will not be changed. If increased attempts to satisfy parents, educate parents as facilitators and usually bring parents in as partners within the children's education fail, then schools should check out providing extra educational support for the children.

\section{Discussion}

In this study, parents have no significant participation in dealing with checking homework and being willing to help their children with homework. The study continued to show that a number of parents spent fewer hours trying to understanding homework. Parents also ruled out any misconceptions about their feelings on school connections and homework showing they could be comfortable in the educational environment.

In this study, lecturers showed the majority did work together for the common good of academic success for all students. However, they did not perceive parents in the same light nor did they give parents a good rating for portraying the importance of or encouraging parental involvement in home 
and school activities. In this study, lecturers' opinion was very high concerning the parent being able to communicate about homework and concerned about those parents who cannot help their students with homework or have the necessary skills to help their child be successful. Lecturers formed a very high opinion of themselves based on that they are very considerate when it came to the needs of the families when giving out homework.

\section{Conclusion}

The results of the study showed that a number of parents were not involved in the education of their children based on the importance of parental involvement. When parents are positively not involved, such as in homework execution and school involvement, it makes not even one significant difference in a child's education. The opinions of lecturers could be rated higher based on the data. As it stands, lecturers have no confidence in parents, yet feel they need to rely on themselves.

The analysis of parental involvement and parental involvement in homework in this study and the emphasis on the need for parental involvement across the board and the literature implicates that schools need to implement to help improve the quality and consistency of parental involvement. The research strongly suggests the need for more restorative practice on the lecturers' part and more ways to improve parental involvement and the importance of schools recognising and disseminating programmes for increasing parent involvement and parent-teacher relationships and communications.

\section{Recommendations}

This research was a very small study, at State Polytechnic of Sriwijaya, with a very homogenous population. In future research, it would be important to survey a larger, less homogenous group to make any broad statements about parental involvement on students' homework and should be focused on ways to encourage both parents and lecturers' involvement in students' homework.

There must be a collaboration between parents and lecturers to facilitate communication about students' homework performance. Strengthening this collaboration will foster parents' efforts to help their children and finally improve children's homework process.

\section{References}

Bempechat, J. \& Shernoff, D. J. (2012). Parental influences on achievement motivation and student engagement. In S. L. Christenson, A. L. Reschly, C. Wylie (Eds.), Handbook of research on student engagement (p. 315-342). Berlin, Germany: Springer Science + Business Media. Retrieved from https://www.researchgate.net/ publication/236685628

Carr, N. (2013). Increasing the effectiveness of homework for all learners in the inclusive classroom. School Community Journal, 23(1), 169-182.

Fan, X. \& Chen, M. (2001). Parental involvement and students' academic achievement: a meta-analysis. Educational Psychology Review, 13, 1-22. doi:10.1023/A:1009048817385

Fox, K. R. (2016). Homework as a family literacy practice: what counts as best practices for children deemed as high risk for academic failure due to socioeconomic status. School Community Journal, 26(2), 215-236. Retrieved from https://www.schoolcommunitynetwork.org/SCJ.aspx

Galloway, M., Conner, J. \& Pope, D. (2013). Nonacademic effects of homework in privileged, high-performing high schools. The Journal of Experimental Education, 81(4), 490-510. https://doi.org/10.1080/ 00220973.2012.745469

Gutierrez, K. \& Rogoff, B. (2003). Cultural ways of learning: individual traits or repertoires of practice. Educational Researcher, 32(5), 19-25. 

12(4), 189-201. https://doi.org/10.18844/ijlt.v12i4.5021

Ibrahim, A. T. \& Jamil, H. B. (2012). The nature of parental involvement in the schooling process in Katsina State. Journal of Education and Learning, 1(2), 37.

Jeynes, W. H. (2010). The salience of the subtle aspects of parental involvement and encouraging that involvement: implications for school-based programs. Teachers College Record, 112, 747-774.

Ramdass, D. \& Zimmerman, B. J. (2011). Development of self-regulation skills: the important role of homework. Journal of Advanced Academics, 22(2), 194-218. doi:10.1177/1932202 X1102200202

Reglin, G., Cameron, H. \& Losike-Sedimo, N. (2012). Effects of a parent support reading intervention on seventhgrade at-risk students' reading comprehension scores. Reading Improvement, 49(1), 17-27.

Sad, S. N. \& Gurbuzturk, O. (2013). Primary school students' parents' level of involvement in their children's education. Educational Sciences: Theory and Practice, 13(2), 1006-1011.

Smith, J., Wohlstetter, P., Kuzin, C. A. \& De Pedro, K. (2011). Parent involvement in urban charter schools: new strategies for increasing participation. School Community Journal, 21(1), 71.

Van Voorhis, F. L. (2011). Adding families to the homework equation: a longitudinal study of mathematics achievement. Education and Urban Society, 43, 313-338.

Vorhees, S. (2011). Why the dog eats Nikki's homework: making informed assignment decisions. The Reading Teacher, 64, 363-367. https://www.jstor.org/stable/41000931

Wilder, S. (2014). Effects of parental involvement on academic achievement: a meta-synthesis. Educational Review, 66(3), 377-397.

$\mathrm{Xu}$, J. \& Wu, H. (2013). Self-regulation of homework behavior: homework management at the secondary school level. The Journal of Educational Research, 106, 1-13. 